\title{
Mujahadah Kamis Wage at Nahdlatul Ulama (NU) Sunan Pandanaran Islamic Boarding School Viewed from Edmund Husserl's Phenomenological Perspective
}

\author{
Annisa Fadlilah \\ IAIN Salatiga, Indonesia \\ aelhasby@gmail.com
}

\begin{abstract}
Mujahadah Kamis Wage, organized by Sunan Pandanaran Islamic Boarding School. It is a religious tradition closely related to NU teachings where there is a teaching to send prayers for parents who have died. Mujahadah Kamis Wage was held to commemorate the death of one of the founders of the Islamic boarding school, namely Nyai Hj. Jauharoh Munawwir died on Kamis Wage. This tradition is a religious phenomenon whose existence can be investigated from all sides. In this study, the Phenomenology of Edmund Husserl is the author's point of view in conducting research. Phenomenology can be used to examine phenomena that occur in a religion, such as ways of worshiping, certain rituals, myths that develop, or the spiritual experiences that followers of religion get after performing certain rituals or worship. Edmund Husserl's phenomenology consists of several steps: Epoche (the act of letting go of oneself), eidetic vision or making ideas, or eidetic reduction by finding the phenomenon's essence and ignoring aspects that are not important. The last step to reach the essence of an object is by transcendental reduction, which leads the researcher to find another picture of the phenomenon beyond the pre-conception limits. This study indicates that the NU tradition phenomenon at Sunan Pandanaran Islamic Boarding School in the form of Mujahadah Kamis Wage is not only limited to the value of religiosity whose implementation relies on religious teachings, but also the social and economic dimensions that go beyond pre-conceptions depending on who follows and interprets it.
\end{abstract}

Keywords: Phenomenology, Religious Tradition, Mujahadah

\section{Abstrak}

Mujahadah Kamis Wage yang diselenggarakan oleh Pondok Pesantren Sunan Pandanaran ini merupakan salah satu tradisi agama yang lekat dengan ajaran NU dimana terdapat ajaran untuk "mengirimkan" doa untuk orang tua yang telah meninggal dunia. Mujahadah Kamis Wage ini 
dilaksanakan untuk memperingati hari meninggalnya salah satu pendiri pondok pesantren yaitu ibu nyai $\mathrm{Hj}$. Jauharoh Munawwir yang meninggal pada hari Kamis Wage. Tradisi ini termasuk fenomena agama yang keberadaanya bisa diteliti dari segala sisi. Dalam penelitian ini Fenomenologi Edmund Husserl menjadi kaca mata penulis dalam melakukan penelitian. Fenomenologi bisa digunakan untuk meneliti fenomena yang terjadi dalam sebuah agama, misalnya cara beribadah, ritual-ritual tertentu, mitos yang berkembang, atau pengalaman spritual yang didapatkan pemeluk agama setelah melakukan ritual atau ibadah tertentu. Fenomenologi Edmund Husserl terdiri dari beberapa Langkah, yaitu: Pertama, Epoche (tindakan menanggalkan diri sendiri), kedua adalah dengan eidetic vision atau membuat ide (ideation) atau reduksi eidetik dengan menemukan intisari dari fenomena dan mengesampingkan aspek yang tidak penting dan langkah terakhir untuk mencapai hakikat suatu objek adalah dengan reduksi transedental yang mengantarkan peneliti menemukan gambaran lain tentang fenomena melebihi batas pra konsepsi. Hasil penelitian ini menyatakan bahwa dalam fenomena tradisi NU di Pondok Pesantren Sunan Pandanaran ini berupa Mujahadah Kamis Wage ini tidak hanya sebatas nilai religiusitas yang pelaksanaannya bersandar pada ajaran agama, tetapi mencakup dimensi sosial dan juga ekonomi yang melebihi pra konsepsi tergantung dari siapa yang mengikuti dan memaknai mujahadah ini.

Kata Kunci: Fenomenologi, Tradisi Agama, Mujahadah

\section{INTRODUCTION}

Islamic boarding schools are one of the target institutions that cannot be separated from the aim of the research. In research on religious rituals, Islamic boarding schools are laboratories for implementing religious ritual actions. The reason is that the Islamic boarding school still preserves certain rituals with a specific purpose. Various types of tirakatan exist in it or are carried out by santri or kyai who live in pesantren, for example, fasting on Mondays and Thursdays which is a general recommendation, fasting ngrowot ${ }^{1}$, mujahadahan ${ }^{2}$ done at night, matang pulub ${ }^{3}$, etc. These rituals

${ }^{1}$ It is an attempt or tirakat to leave food that comes from rice seeds. The doer does not only avoid consuming rice but are also accompanied by reading the practice during tirakat. This practice is in the form of dhikr which is read after performing the five daily prayers. 
have different purposes from one another. This ritual order usually comes directly from the Kyai for all students or students with a special purpose for Ijazab ${ }^{4}$ from Kyai.

Ritual phenomena in each Islamic boarding school can be different from one another. But broadly speaking, Islamic boarding schools cannot be separated from this phenomenon, especially those with the NU ideology. It contrasts to some modern Islamic boarding schools with neutral backgrounds whose ritual intensity in their activities may be smaller than those of $\mathrm{NU}$ pesantren. For example, Hadi Al-Iman Boarding School at MAPK Surakarta does not have any special rituals. It is different from the NU Al-Muayyad Islamic Boarding School, both located in Surakarta, which still preserves many special rituals, such as performing the tasbih prayer on the night of $21^{\text {st }}$ Ramadan, matangpulub for those who memorize al-Qur'an, and so on.

One of the Islamic boarding schools in Yogyakarta, the author's research location, is Sunan Pandanaran Islamic Boarding School, located on Jalan Kaliurang Km. 12.5 Ngaglik, Sleman, Yogyakarta. The Islamic Boarding School taken care of by KH. Mu'tashim Billah, M.Pd.I has routine activities every Kamis Wage , ${ }^{5}$ officially named Pengajian dan Mujahadah Kamis Wage but more familiar with the term Mujahadah Kamis Wage . One of the rituals preserved by this Islamic boarding school certainly has a specific purpose and background.

The author uses a phenomenological approach to study Mujahadah Kamis Wage at the NU Sunan Pandanaran Islamic Boarding School. This phenomenological approach is then specified by the author of the phenomenology of Edmund Husserl. This approach limits the direction from which the author looks at Mujahadah Kamis Wage and how the author responds to the phenomena. This approach minimizes research results that only support the researcher's ideology so that the research object can speak and reveal the results correctly. wirids.

${ }^{2}$ Mujahadah is a series of religious activities that usually contain certain prayers and

${ }^{3}$ Doing the completion of the Qur'an every day for forty days accompanied by fasting.

${ }^{4}$ Unwritten permission given by the teacher to his students, or the kyai to his santri.

5 Third day in Javanese calendar. 
The consequence of this approach is that there is no longer a religious ritual seen according to the doer. Still, a ritual is seen as the ritual itself that reveals, regardless of who the perpetrator is. For this reason, to study Mujahadah Kamis Wage at the NU Sunan Pandanaran Islamic Boarding School, the author chose a phenomenological approach as a guideline in observing.

\section{RESEARCH METHODOLOGY}

In this research, the writer uses the descriptive-qualitative research method. Descriptive research seeks to describe phenomena that occur in a real, realistic, and actual way. ${ }^{6}$ This descriptive method is used to describe the reality of Mujabadah Kamis Wage conducted at the NU Sunan Pandanaran Islamic Boarding School to provide a relatively complete picture of the spiritual reality in Mujahadah Kamis Wage.

This qualitative research method is used so that the author can explore and understand the meaning that comes from social or humanitarian problems. Qualitative research models focus on the meaning and translate the complexity of a problem. ${ }^{7}$ The qualitative method also functions in determining the focus of research, selecting valid informants as data sources, assessing data quality, analyzing data, and making conclusions on the findings related to the phenomenon of Mujabadah Kamis $W$ age at the NU Sunan Pandanaran Islamic Boarding School. ${ }^{8}$

\section{DISCUSSION}

\section{Edmund Husserl Phenomenological Approach Definition of Phenomenology}

Phenomenology comes from the word "phenomena." In English, it is called phenomenon or phenomenon etymologically means manifestation, event, or symptom. This word comes from the Greek phenomenon,

\footnotetext{
${ }^{6}$ Ajat Rukajat, Pendekatan Penelitian Kuantitatif: Quantitative Research Approach, Print: I Deepublish, 2018, Yogyakarta: Page:1.

${ }^{7}$ John W.Creswell, Research Design Pendekatan Kualitatif, Kuantitatif, dan Mixed (Yogyakarta:Pustaka Pelajar, Third Edition, 2009), 5.

${ }^{8}$ Sugiyono, Metode Penelitian Kuantitatif Kualitatif dan R\&D (Bandung: CV. Alvabeta, 2010), p. 222.
} 
which is seen because it covers. " Phenomenology is the study of phenomena or visible phenomena. ${ }^{10}$ In the Big Indonesian Dictionary, phenomenology is the science of developing human consciousness and self-knowledge as a science that precedes philosophy or part of philosophy. ${ }^{11}$ In a broad sense, phenomenology is used to see everything visible. The origin of this term is used to distinguish visible things (phenomenon) and things that are not visible (noumenon). ${ }^{12}$

By its constituent words, it can be concluded that phenomenology is a method to see phenomena that occur under human consciousness, both as actors and as observers. This phenomenon can include anything in human life, both as individuals, social and religious beings that cannot be separated from ritual phenomena.

Edmund Husserl was not the first to come up with this term. It had been previously introduced by Lambert, Immanuel Kant, and Plato. They stated that phenomenology is the study of a phenomenon from one's consciousness. It is a phenomenologically described body experience. ${ }^{13}$ Meanwhile, Palmer defines phenomenology as letting things become clear as they are. ${ }^{14}$ Although some of its predecessor philosophers have introduced it, there is a consensus that Edmund Husserl was the one who pioneered the use of the term phenomenology as a branch of philosophy that was packaged systematically. ${ }^{15}$

If it is associated with Islamic studies, this approach can be used in researching phenomena that occur in a religion, such as ways of worship, certain rituals, myths that develop, or the spiritual experiences that adherents get after performing certain rituals or worship. This paper uses phenomenological glasses to see Mujahadah Kamis Wage at the NU Sunan Pandanaran Islamic Boarding School. 179.

${ }^{9}$ Juhaya S. Praja, Aliran-Aliran Filsafat \& Etika (Jakarta: Kencana, 2014), Print: V, p.

${ }^{10}$ K. Bertens, Filsafat Barat dalam Abad XX (Jakarta: Pt. Gramedia. 1981), p.109.

${ }^{11}$ Big Indonesian Dictionary Offline Application.

12 Alex Sobur, Filsafat Komunikasi; Tradisi dan Metode Fenomenologi, (Bandung: PT. Remaja Rosdakarya, 2013) Print. I, p 15

${ }^{13}$ Alo Liliweri, in the introduction of the book Filsafat Komunikasi; Tradisi dan Metode Fenomenologi, (Bandung: PT. Remaja Rosdakarya, 2013). p.iii

${ }^{14}$ Alex Sobur, Filsafat Komunikasi..., p.18

${ }^{15}$ Ibid. p.20 


\section{Phenomenological Scope}

Before its development, phenomenology was used to refer to all social science views that placed human consciousness and its subjective meaning as the focus for understanding one's social actions. Looking at the root of the word phenomenology from the word phenomenon, it has the same basis as the roots of fantasy, phantom, phosphor, and photo, which means light. The word phenomenon means "which is seen because it shines" from this word. ${ }^{16}$

In a broader sense, the word phenomenology includes various popular ways of talking about phenomena or things that appear. In other words, the scope of phenomenology is about "phenomena." Heinrich Lambert first introduced the term in 1764 to refer to the theory of sightings. He used the term phenomenon for an imaginary picture of human experience, which later defined phenomenology as a fantasy theory. ${ }^{17}$ Meanwhile, a contemporary philosopher with Lambert, Kant, defines phenomenology by distinguishing between objects and events that appear in our experience (phenomena) with objects and events in themselves and are missed by the senses (noumena). ${ }^{18}$

One of the idioms juxtaposed with phenomenology is religion. The phenomenology of religion uses comparison as the main means of interpretation to understand the meaning of religious expressions such as sacrifices, rites, gods, etc. ${ }^{19}$ In the phenomenology of religion, the focus study is to find the deepest meaning of a religious expression of religionthe method of comparing the religious acts of different individuals to find common ground behind these actions. In short, phenomenology makes real experience the main data of reality. Palmer said, "all you can know is what you have experienced, which means letting things be clear as they are." 20

${ }^{16}$ Ibid. p. 15

${ }^{17}$ Ibid. p. 16

${ }^{18}$ Ibid. p. 17

19 Mariasusai Dhavamony, Fenomenologi Agama, (Yogyakarta: Penerbit Kanisius, 2006) p. 42.

${ }^{20}$ Alex Sobur, Filsafat Komunikasi..., p. 18 


\section{Edmund Husserl Biography}

Edmund Husserls was born in Moravia, Austria, on April $8^{\text {th, }} 1859$, to the parents of Abraham Husserl and Julie Husserl nee Selinger. His parents gave him the name Edmund. In 1876 he went to Leipzig to study mathematics and natural sciences and met Wilhelm Wundt, the founder of experimental psychology, for two years and returned to Berlin then to Vienna and completed his dissertation on calculus in $1883 .{ }^{21}$ His first work, Philosophie der Arithmetik (Philosophy of Arithmetic), did not clearly mention phenomenology. It was only in his Logicche Untersuchungen (Inquiry of Logic) that ideas about phenomenology began to appear. This idea was continued in his work entitled Ideen Zueier Reinen Phanomenologie und Phanomenologischen Philosophie (The Idea of a Pure Phenomenology and A Phenomenological Philosophy) in $1939 .{ }^{22}$

His career in philosophy began at Halle University at the age of completing his thesis on the concept of numbers. He became a lecturer at the university from 1887 until 1901, moved to Gottingen, and became an assistant professor for the next 15 years. In Gottingen, he formed a small group with Gottingen students and discussed issues of phenomenology. Furthermore, Husserl actively gave lectures on phenomenology at several universities in London, Prague, Vienna, and Paris, which his assistant in Freiburg then continued, Martin Heidegger, after his retirement came. ${ }^{23}$

\section{Edmund Husserl's Phenomenology}

Husserl's phenomenology is always associated with intentionality, which comes from the Latin intendere, stretching forward. ${ }^{24}$ In simple terms, intentionality is the action of the mind to direct itself to an object to translate it into a meaningful experience. Husserl emphasized that human consciousness is intentional, meaning that all consciousness is always an awareness of something.

\footnotetext{
${ }^{21}$ Ibid. p. 40

22 Ibid. p. 41

${ }^{23}$ Ibid, p. 42

${ }^{24}$ M.A. Subandi, Psikologi drikir: Studi Fenomenologi Pengalaman Transformasi Religius, p. 61
} 
Husserl likens a flashlight aimed at an object to be clearly visible. In other words, consciousness always goes hand in hand with objects, material objects such as chairs, cars, or other objects, or abstract ones such as ideas. ${ }^{25}$ In Husserl's phenomenology, consciousness translates phenomena from the world around us that we are not familiar with. Intentionality consists of two interrelated experiences, namely noem $a^{26}$ and noesis. ${ }^{27}$ Noema refers to an object that can be seen, observed, and felt, whereas noesis ${ }^{28}$ is the subject who sees, observes, and feels. These two things are interrelated because when we talk about an object of experience, the question automatically arises of how that experience can be experienced.

In addition to the form of experience, Husserl categorizes the characteristics of the living world, namely the living world is in space and time, the world has various regularities, and that the world appears in certain relativity to the subject experiences it. ${ }^{29}$ Husserl places intentionality as an important part of seeing things or phenomena. In the process of a phenomenon, there is a relationship between the subject who observes or feels the phenomenon and the phenomenon itself.

\section{Steps of Husserl's Phenomenology}

As an approach to studying phenomena, phenomenology has special steps that must be taken: First, Epoche (the act of letting go of oneself). The word epoche comes from the Greek, "to postpone a decision" or "to abstain from a certain belief." Epoche can also mean brackets for any information obtained from a phenomenon that appears without giving a right or wrong decision first.

As a first step, the researcher must empty the knowledge in his mind about the object of research and let the object happen as it should without any judgment from the researcher. In other words, a researcher is required to maintain objectivity and see phenomena as they occur. In this

${ }^{25}$ Ibid. p. 62

${ }^{26}$ Noema in phenomenology is the object of consciousness. In direct contact with the object.

${ }^{27}$ Ibid.

${ }^{28}$ Noesis in phenomenology is awareness of objects. Deal directly with the doer who saw the object.

${ }^{29}$ Ibid. p. 64 
case, Husserl said that epoche is a thesis of natural standpoints, in the sense that phenomena that appear in consciousness are truly natural without being interfered with by the observer's thoughts. In other words, this step is where the researcher forgets the notions of objects for a while and tries to see the object directly with intuition without the help of previous understandings. ${ }^{30}$ Husserl calls this step a phenomenological reduction, which excludes all knowledge about an object, even though it does not discard it as a whole. ${ }^{31}$

The second step is the eidetic vision or making an idea (ideation) or eidetic reduction. In this case, researchers must filter the observed phenomena and understand the ideas contained in them. This step leads the researcher to uncover what is presented by the phenomenon he is studying. The important point in this research is the absence of interference from the ideas brought by previous researchers. Research with this approach comes from the actors or subjects who experience certain phenomena under study. Even though the researcher is an outsider, he must experience or act as an insider who concludes research based on the phenomena that occur as they are. This step will be found in how an object works without being accompanied by the researcher's assumptions.

In addition to these two steps, a transcendental reduction is the last step to reach the essence of an object. This step is no longer about emptying assumptions about phenomena or objects but is directed to the subject concerning transcendental self-awareness. This step unites the object into the subject, which is free from practical experience so that the subject can express what happened to the object definitely beyond the pre-conception limits. ${ }^{32}$ With these three steps, a phenomenon is no longer seen as who the doer is but how the phenomenon occurs and how other people see it as a phenomenon as itself, regardless of who the phenomenon is from.

In other words, as a methodology, phenomenology tends to use qualitative methods by conducting participant observations, open

${ }^{30}$ Juhaya S. Praja, Aliran-Aliran... p.. 180.

31 Shofiyullah MZ, Fenomenologi Edmund Husserl (Suatu Pendekatan Memahami "Ketegangan" Religiusitas) in Esensia Journal Vol. 3, No. 2, July 2002, p. 257

${ }^{32}$ Ibid. p. 259 
JNUS: Journal of Nahdlatul Ulama Studies, Vol. 2, No. 2, Juli 2021: 119-137

interviews, and personal documents. This method generates descriptive data to see the world as the subject sees it. ${ }^{33}$

\section{Mujahadah Kamis Wage at the NU Sunan Pandanaran Islamic Boarding School}

The implementation of Mujahadah Kamis Wage at the NU Sunan Pandanaran Islamic Boarding School started from the mujahadahan, which is held every Thursday and is in the third complex of Sunan Pandanaran Islamic Boarding School. This ritual has been carried out since 2001. This ritual activity usually starts on Wednesday after the Maghrib prayer, which in the Hijri calendar is the beginning of the day, followed by the simaan of the Qur'an. Simaan of the Qur'an is divided into several groups and carried out by the students who have completed the Qur'an. This event was then continued Thursday afternoon after the Asr prayer with tabtiman, recitation, and mujahadah events.

This wage ritual activity was initiated by K.H Mufid Mas'ud, who desired to make regular selapanan recitations. ${ }^{34}$. The election of Thursday Wage was to commemorate Nyai $\mathrm{Hj}$. Jauharoh Munawwir died on Thursday Wage. Mujahadah Kamis Wage activity was attended by Sunan Pandanaran Islamic Boarding School students and the wider community. The participants of this Thursday's ritual now reach 2500 congregations. ${ }^{35}$

The activity of Mujahadah Kamis Wage usually arranged with several agendas, namely (1) Khataman Al-Qur'an, (2) Prayer for Khataman AlQur'an, (3) Religious Lecture, (4) Reading Asmaul Husna, (5) Reading Ratiibul Haddad, (6) Reading Kasidah Ibaadallah, and (7) Sholawatan followed by shaking hands.

Mohamad Yahya explained that the structure of the wirid contained in Mujahadah Kamis Wage is divided into four reading groups.

${ }^{33}$ Robert Bogdan dan Steven J. Taylor, Introduction to qualitative research methods; A Phenomenological Approach to the Social Science. Tjmh. Arief Furchan, Pengantar Metode Penelitian Kualitatif: Pendekatan Fenomenologi dalam Ilmu Sosial, (Surabaya: Usaha Nasional, 1992) p. 19

34 Selapanan is the cycle of days in the Javanese calendar which each period is 35 days.

35 M, Nasrudin dkk, "Pelaksanaan Pengajian Mujahadah Kamis Wage Bagi Peningkatan Kualitas Bacaan Berbahasa Arab Jamaah" in Jurnal Nuansa Akademik Vol 6 No 12021 p.. 95 
The first is the Qur'an contained in the Khataman and Ratiibul Hadad processions. Then, praising Allah and His Messenger contained in Ratibul Hadad and Asmaul Husna. The Kasidah contained in the Ratiibul Hadad, and sholawat is the third group. While the fourth is the prayers. Furthermore, he considered that readings other than the Qur'an and sholawat could be included in the category of bid'ah, which was never done by the prophet. Still, if you look at the structure of the wirid, he categorizes this activity into the living phenomena of hadith. ${ }^{36}$

\section{The Analysis of Mujahadah Kamis Wage at NU Sunan Pandanaran Islamic Boarding School from the Phenomenological Perspective of Edmund Husserl}

At the application level, to construct Mujahadah Kamis Wage at the NU Sunan Pandanaran Islamic Boarding School through Edmund Husserl's phenomenology, the author used several steps. First, the author conducted an epoche in this Mujahadah Kamis Wage by eliminating the basic assumption that the activity is an obligation that must be carried out because it comes from religious teachings. In contrast, ritual activity is a sinful activity that is prohibited in Islam. Second, the writer made eidetic reduction by looking into how this phenomenon works. By following directly, you will get the right description and what is there, as the author described previously. ${ }^{37} \mathrm{By}$ seeing how this routine works, assumptions that are unimportant and not the essence of this ritual can be removed.

Third, after putting aside the initial assumptions and following the routine directly with the help of the people who follow it, it will arrive at a transcendental reduction as the third step. An understanding of how the Kamis Wage phenomenon is no longer needed to be viewed from any angle, but that's how it happened and fused in the minds of each actor. There is no longer any question about how it happened, the law, and who carried it because the picture and understanding have been clearly seen and finally left it as it is and continues to run as it should.

${ }^{36}$ Mohamad Yahya, Fungsi Pengajian dan Mujahadah Kamis Wage bagi komunitas Pesantren Sunan Pandanaran, Sleman Yogyakarta, Living Hadis Journal, Volume 1 Nomor 1, May 2016. p. 70.

${ }^{37}$ Look at "Sekilas tentang Kamis Wage di Pondok Pesantren Sunan Pandanaran" p. 2. 


\section{Epoche in Mujahadah Kamis Wage}

Mujahadab Kamis Wage has various perspectives regarding its implementation function. For example, M. Nasrudin argues that the implementation of Mujahadah Kamis Wage has a function to improve the quality of students in Arabic because the readings in the ritual use Arabic a lot. $^{38}$ It is slightly different from Mohamad Yahya who argues that the functions of implementing Mujahadah Kamis Wage are numerous and intertwined with each other in several ways, namely religion, psychobiology, education, ideology-sectarian, socio-political-power, economic, and social culture in general. ${ }^{39}$

According to the author, some of the interesting functions of sectarian ideology are expressed by M. Yahya. According to him, the function of this sectarian ideology relates to the position of Sunan Pandanaran Islamic Boarding School, which has an ideological affiliation to the Nahdlatul Ulama $(\mathrm{NU})$ community organization. This ritual relates to the agenda of several mass organizations carrying out the anti-heretic movement in Islam. However, regardless of whether this activity is a counter activity to the anti-bid'ah movement that several Islamic organizations are promoting, in fact, the increasing number of participants to 2500 , for the author, is proof that there is a need from the community in the implementation of this Mujahadah Kamis Wage.

The concept of Epoche in this phenomenological research stage led the author to eliminate assumptions and outside opinions related to the Kamis Wage activity ritual at the NU Sunan Pandanaran Islamic Boarding School. In the next stage, the writer will see and explain the course of this activity without bringing any assumptions that can narrow the writer's point of view as a researcher.

\section{Eidetic Reduction}

The eidetic reduction stage led the writer to describe how the activities of Mujahadah Kamis Wage were running. This activity was carried out with

\footnotetext{
${ }^{38}$ M, Nasrudin dkk, Pelaksanaan Pengajian..., p.. 94

${ }^{39}$ Mohamad Yahya, Fungsi Pengajian..., p.. 69
} 
several agendas, namely (1) Khataman Al-Qur'an, (2) Prayer of Khataman AlQuran, (3) Religious Lectures, (4) Reading Asmaul Husna, (5) Reading Ratiibul Haddad, (6) Reading Ibaadallah Kasidah, and (7) Sholawatan followed by shaking hands.

Khataman al-Qur'an started the day before, namely Wednesday night, which has entered the beginning of Kamis Wage according to the Islamic calendar. This finishing activity is carried out by students who have completed 30 chapters of the Qur'an and are carried out using the sima'an method. This simaan was carried out by several students from the beginning of the chapter's name the Qur'an to the al-Lail. It is because the recitation of the Qur'an will be continued when this event takes place formally in the arrangement of Mujahadah Kamis Wage activities. Sema'an activities ended on Thursday afternoon.

There is an unwritten agreement running from year to year, namely the big family of Sunan Pandanaran Islamic Boarding School wearing white clothes, both from the ndalem family, students, and teachers in the environment and the surrounding community who follow Mujahadah Kamis Wage. For male students, the costumes are white caps and white robes, while for women, any white clothes can be suits or robes. This white costume was the official costume of K.H Mufid Mas'ud when he was still alive in attending official boarding school events. ${ }^{40}$

The reading of ad-Dhuba to an-Nas was continued in a formal event, followed by tablil and closed with a prayer for completing the Qur'an. After the prayer process was addressed to the prophet Muhammad, the Companions, Tabiin, the Ulama and Auliya', the Masyayikh of al-Qur'an, Sheikh Munawwir bin KH Hasan Bashori, KH Mufid Mas'ud, Nyai Hj Jauharoh, all parents and students as well as teachers and members of Mujahadah Kamis Wage congregation. It can be seen from the reading of Hadhoroh and the prayer that is read.

The implementation of the next activity, namely a religious lecture, this religious lecture material contains about aqidah, shari'ah, and morals that relate to everyday life in society. The delivery of language in this religious lecture is usually mixed between Indonesian, Javanese, and Arabic. This lecture was filled by the kyai and gus in the environment of

${ }^{40}$ Mohamad Yahya, Fungsi Pengajian..., p. 65. 
JNUS: Journal of Nahdlatul Ulama Studies, Vol. 2, No. 2, Juli 2021: 119-137

Sunan Pandanaran Islamic Boarding School. Not infrequently, the content of lectures also invites the public to choose Islamic boarding schools as children's character education.

The next activity is reading Asmaul Husna. This activity does not directly mention its Asmaul Husna in its recitation. Still, it uses the Asmaul Husna wa Du'aiba verse, which begins with Bismillahi Bada'na and ends with Shalli Wa Sallim alaa thoha Khalililirahman waalibi wa shabbibi ilaa akbiri zaman. This reading is carried out jointly by the congregation led by one officer who uses a loudspeaker.

The recitation of Ratiibul Hadad, which was held in Mujahadah Kamis Wage was preceded by the reading of al-Fatibah, then continued with the reading of several verses in the Qur'an and prayers that were repeated several times. Ratibul Hadad reading ends with the reading of al-Ikhlas, alFalaq and an-Nas and continues with prayers. The prayer reading in Mujahadah Kamis Wage is the same as the ratiibul hadad assigned by the teacher from the kyai even without any change in the tone of the reading.

The reading of Kasidab Ibaadallab is a reading of praise in religion. It is a reading taken in the manakib of Sheikh Abdul Qodir Al-Jaelani. After the recitation, it is then continued with the reading of Sholawat Burdah (Maula ya shalli wa sallim daaiman Abada). It usually ends the implementation of Mujahadah Kamis Wage, but at certain moments it is continued by shaking hands from the santri to the kyai at the boarding school.

At the end of the event, the students, alumni, and the community who participated began to leave the study location. This activity is usually finished before the Maghrib prayer and continued with the Maghrib prayer in the congregation for the big family of Sunan Pandanaran Islamic Boarding School and people who want it.

\section{Transcendental Reduction}

Transcendental reduction is the last step in looking at religious phenomena, the Kamis Wage activity at the NU Sunan Pandanaran Islamic Boarding School. Transcendental reduction leads the writer to see from various sides related to this phenomenon. To get a comprehensive view of this religious phenomenon, the author interviewed several sources as doers who participated in Kamis Wage activity. 
Mujahadah Kamis Wage activity was initially held in the second complex of the NU Sunan Pandanaran Islamic Boarding School. Still, after being deemed unable to accommodate the growing number of participants, this activity was moved to the third complex with a good place. It is related to the continued increase in visitors who participate in the recitation, both from the increasing number of students, alumni who still attend, and the public who regularly attend. During the pandemic, which prohibits events that cause crowds, Kamis Wage is still running but only for internal circles or the ndalem family and santri who are living in residence. Due to the request of the community and alumni who still want to participate, finally, this activity can be followed online. ${ }^{41}$

The author took part in this activity when this activity was still being carried out in the second complex. With the background of the general category, the author felt that this Selapanan Kamis Wage activity resembled a haul activity usually carried out in other Islamic boarding schools. The presence of the public in participating in this activity opened a space for community closeness. And Islamic boarding schools or institutions are sometimes inaccessible to the public in their religious activities. People who do not only come from around the NU Sunan Pandanaran Islamic Boarding School from within Yogyakarta, Magelang, to Purworejo also take the time to come there. Of course, amid the busy city of Yogyakarta with its worldly activities, this Mujahadah Kamis Wage is missed as a balance in life. ${ }^{42}$ The solemnity and honor felt while participating in this mujahadaban indeed cannot be separated from the religiosity side where this religious phenomenon is based.

The original purpose of this event was to commemorate the death of the founder of the NU Sunan Pandanaran Islamic Boarding School, Nyai Hj. Jauharoh, the wife of K.H. Mufid Mas'ud. Usually, the anniversary of someone's death in NU teachings, especially in Java, is commemorated starting from three days, seven days, 40 days, 100 days, one year, and 1000 days. Praying for parents who have died is one of the characteristics of nabdliyin tradition, which relies on this teaching on the

${ }^{41}$ Interview with Ulya Sabila, an alumnus of the Islamic Boarding School Sunan Pandanaran in 2018, on August 7, 2021.

${ }^{42}$ Interview with Najmi's mother, a resident around the NU Sunan Pandanaran Islamic Boarding School who attended Mujahadab Kamis Wage. 
hadith of the prophet narrated by Imam Muslim. It states that "If a person dies, his deeds will also be cut off, except for Sadaqah Jariyah, useful knowledge and pious children who pray for their parents.". Being a pious child who prays for his parents and teachers who have died, it is hoped that it will become a provision for the deceased. This tradition, which is related to NU teachings, further strengthens the ideology of the pesantren with a nabdliyin spirit since its inception.

Starting from this goal, Mujabadah Kamis Wage is different because it is commemorated during the selapanan period. Although this mujahadah is to commemorate the death, in its implementation, it is not only for one name that is prayed for, but the entire extended family that has preceded. It doesn't stop there, mujahadah that internal members initially attended has become a routine activity that is also open to the public. It shows that this activity is no longer an internal interest of the lodge but has developed according to the needs of the times. This activity is also a path of da'wah for both the surrounding community and the public. This slowly embracing da'wah is in demand by the community to fulfill spiritual needs amid worldly activities.

In addition to the religious side, there is another side that the writer needs to reveal in this activity. Mujabadah Kamis Wage closed the access road around the lodge. With the closure of this road, the community has access by selling and trading around the Islamic boarding school to seek fortune. Some residents depend on their economic income from selling activities around the cottage during Mujabadah Kamis Wage activity. Many new snacks are found along the streets of the NU Sunan Pandanaran Islamic Boarding School complex that are not found on normal days. By what Azyumardi Azra stated, the traditional functions of pesantren are three things: the transfer of Islamic knowledge, the maintenance of Islamic traditions, and the reproduction of scholars. Along with changes in social conditions, Azra argues that currently, pesantren in the archipelago have carried out many function transformations, such as becoming centers of economic empowerment for the surrounding community or other social functions. ${ }^{43}$

${ }^{43}$ Mohamad Yahya, Fungsi Pengajian..., p. 75 
The awareness of the religious phenomena seen by this author is different from that experienced by the two authors' respondents related to their experiences in participating in this activity. Ulya Sabila, a student and at the same time alumni of the NU Sunan Pandanaran Islamic Boarding School, revealed that Mujahadah Kamis Wage activity was an activity that she longed to participate in when she graduated from the Pandanaran Islamic boarding school. After graduating from the Sunan Pandanaran, she stated that she still participated in several activities because there was a special longing to follow. She did not want to miss a nostalgic feel when following this activity again. She felt an inner comfort that could not be replaced by activities in other places even though they are similar.

Ulya added that the readings in Mujahadah Kamis Wage had been memorized because of the long and frequent participation in this activity. According to her, one of the main factors that led to the memorization of these readings was the obligation to participate in this activity for students and female students who lived in Sunan Pandanaran Islamic Boarding School.

Asfa, one of Sunan Pandanaran Islamic Boarding School students who lived in the third complex, also revealed this obligation. She said that Kamis $W$ age was an activity that the students eagerly awaited. Students even used the term "Kamis Wage" to ask schoolteachers for holidays or reduce learning hours because the learning process in class would be adjusted to the continuity of Kamis Wage activities. ${ }^{44}$ She added that Kamis Wage activity was a fun activity for the students because the students could go out and walk around the lodge, and there were lots of snacks offered by the local community. According to her, Kamis Wage activity became something that students waited for.

Ulya stated that every time she participated in Kamis Wage activity when she was an alumnus, she was never inside the cottage of the third complex as the center of activities. She usually arrived later because her attendance could be more flexible than when she was a student at the Islamic boarding school. She usually followed the momentum of Mujahadah Kamis Wage by sitting outside the school's location and

${ }^{44}$ Interview with Zayyina Millati Ashfa, Santri of NU Sunan Pandanaran Islamic Boarding School. 
following along with the people who sit outside the cottage area. She still finished the readings in Mujahadah Kamis Wage with the reading leader, whose voice was only heard from the loudspeaker. It was different from Asfa, a NU Sunan Pandanaran Islamic Boarding School student. She admitted that the students must follow in the cottage area from the start to end of this activity. The students usually went to the second complex before finally being moved to the third complex, at noon heading to Mujahadah Kamis Wage event and then returning to their respective complexes after the event was over. According to her, the process of traveling from the lodge to the event area was what she had been waiting for because along the road there were a lot of vendors selling food that was usually not available on days other than Kamis Wage. Getting a little view outside the cottage and being free to "snack" is a separate entertainment for students who cannot leave the cottage area daily.

In the end, none of the subjects who experienced the awareness of religious phenomena in Mujahadah Kamis Wage activity could be judged right or wrong. This phenomenon has occurred and is seen by each doer who experiences it consciously.

\section{CONCLUSSION}

The phenomenological approach in viewing Mujabadah Kamis Wage at Sunan Pandanaran Islamic Boarding School is one way that can be used in researching religious phenomena in Islam. With this approach, a compromise between the reality of a phenomenon and assumptions about the phenomenon can be made. The objectivity of research can also be improved by allowing phenomena to reveal the facts themselves without any specific ideological or theological limitations.

Husserl's phenomenology can be a tempting offer to avoid the disease of society in religion, which is increasingly mushrooming, namely feeling that one's beliefs are the most right and others are wrong. If this problem is not immediately resolved, religious harmony, one of Indonesia's ideals, will only remain an unrealized dream. Borrowing Shofiyullah MZ's term in his writings on Phenomenology in the Esensia journal that Muslims should return to Islam with a big "I," namely universal Islam and rohmatan Lil Alamin, not only Islam with a small "i," 
which means Islam itself is right and the other group is wrong. ${ }^{45}$ The role of NU in Sunan Pandanaran Islamic Boarding School is important in spreading religion that embraces the surrounding community to be religious in a friendly and non-exclusive manner that is not touched by "outsiders. Then, when the question arises about the objectivity of the method whose results depend on the doer, phenomenology experts consider the truth of the results of this research not as an objective view but as a mixed picture of a phenomenon. Just as people have different opinions about the same thing, one person can have different opinions about the same theme at different times. ${ }^{46}$

\section{REFERENCES}

Bertens. K. 1981. Filsafat Barat dalam Abad XX.. Jakarta: Pt. Gramedia.

Bogdan, Robert dan Steven J. Taylor. 1992. Introduction to qualitative research methods; A Phenomenological Approach to the Social Science. Tjmh. Arief Furchan, Pengantar Metode Penelitian Kualitatif: Pendekatan Fenomenologi dalam Ilmu Sosial. Surabaya: Usaha Nasional.

Dhavamony, Mariasusai. 2006. Fenomenologi Agama. Yogyakarta: Penerbit Kanisius.

https://id.wikipedia.org/wiki/Fenomenologi accessed on August 4th, 2021

M.A. Subandi. 2009. Psikologi drikir: Studi Fenomenologi Pengalaman Transformasi Religius. Yogyakarta: Pustaka Pelajar.

Muslih, Moh. 2008. Filsafat Ilmu; Kajian atas Asumsi Dasar, Paradigma, dan Kerangka Teori Ilmu Pengetahuan. Yogyakarta: Penerbit Belukar, $5^{\text {th }}$ print.

Praja, Juhaya S. 2014. Aliran-Aliran Filsafat \& Etika. $5^{\text {th }}$ print. Jakarta: Kencana.

Shofiyullah MZ, Fenomenologi Edmund Husserl (Suatu Pendekatan Memahami "Ketegangan" Religiusitas) in Esensia Journal Vol. 3, No. 2, July 2002 Sobur, Alex. 2013. Filsafat Komunikasi; Tradisi dan Metode Fenomenologi, $1^{\text {st }}$ Print. Bandung: PT. Remaja Rosdakarya.

\footnotetext{
${ }^{45}$ Look at Shofiyullah MZ, Fenomenologi..., p. 260-261

46 Robert Bogdan dan Steven J. Taylor, Introduction...p. 30
} 